\title{
Pengaruh Lama Perebusan terhadap Kualitas Kimia dan Organoleptik Abon dari Bagian Dada dan Paha Ayam Petelur Afkir
}

\author{
Eko Prasetyo, Adi Magna Patriadi Nuhriawangsa dan Winny Swastike \\ Program Studi Peternakan, Fakultas Pertanian, Universitas Sebelas Maret \\ Jl. Ir. Sutami 36A Kentingan, Jebres, Surakarta 57126 \\ E-mail: magnapatriadi67@yahoo.com
}

\begin{abstract}
ABSTRAK
Penelitian bertujuan untuk mengetahui pengaruh lama waktu perebusan dan lokasi otot serta interaksi kedua faktor tersebut terhadap kualitas kimia dan organoleptik abon ayam petelur afkir. Sampel yang digunakan adalah daging ayam petelur afkir bagian dada dan paha. Rancangan menggunakan Rancangan Acak Lengkap (RAL) Pola Faktorial 2 x 3. Faktor pertama lama perebusan (15, 30, 45 menit) dan faktor kedua lokasi otot (dada dan paha). Kadar air diuji secara Gravimetri, kadar lemak secara ekstraksi Soxhlet, kadar protein secara Buret dan kualitas organoleptik meliputi juisi, flavor dan kesukaan. Kadar air dan protein abon dipengaruhi $(\mathrm{P}<0,01)$ oleh lama waktu perebusan dan lokasi otot. Flavor dan kesukaan tidak dipengaruhi lama waktu perebusan dan lokasi otot. Juisi dipengaruhi $(\mathrm{P}<0,01)$ terhadap lokasi otot, tetapi tidak oleh waktu perebusan. Daging dada dengan perebusan 30 menit dan daging paha dengan perebusan 45 menit mempunyai kualitas terbaik.
\end{abstract}

Kata kunci: abon, dada, paha, lama perebusan, kualitas kimia, organoleptik.

\section{Influence of Boiling Time on Chemical and Organoleptic Quality of Breast and Leg Parts Abon of Post Laying Hens}

\begin{abstract}
The aim of this study was to determine the effect of boiling time and muscle parts and the interaction of those two factors on chemical and organoleptic quality of abon of post laying hen. Poultry meat samples used were breast and thigh of post laying hens. The design used was Completely Randomized Design of Factorial Pattern $2 \times$ 3. The first factor was boiling time (15, 30, 45 minutes) and the second was muscle parts (breast and thigh). Water content was tested by Gravimetric, fat content by Soxhlet extraction, protein content by Buret and quality of organoleptic included juicy, flavour and preference. Water and proteins content were affected $(P<0.01)$ by boiling time and muscle parts. Flavor and preferences were not affected by boiling time and meat type. Juicy was affected $(P<0.01)$ by muscle location. Breast meat with boiling 30 minutes and thigh meat with boiling 45 minutes have the best quality.
\end{abstract}

Keywords: abon, breast, leg, boiling time, chemical quality, organoleptic. 


\section{PENDAHULUAN}

Ayam petelur afkir adalah ayam betina petelur dengan produksi telur rendah sekitar 20 sampai 25\% pada usia sekitar 96 minggu dan siap untuk dikeluarkan dari kandang (Gillespie and Flanders, 2010). Ayam petelur afkir oleh peternak dimanfaatkan sebagai ayam potong untuk penghasil daging dan mempunyai kualitas daging lebih rendah dibanding ayam broiler, karena mempunyai bau spesifik dan alot, tetapi merupakan sumber penghasilan baru bagi peternak jika harga jual tinggi (Rasyaf, 2010).

Daging ayam petelur afkir memiliki potensi untuk menjadi produk daging olahan, karena mempunyai kandungan nutrien tidak jauh berbeda dengan daging ayam broiler dan mempunyai kandungan lemak tinggi (Rasyaf, 2010). Kandungan lemak pada daging menentukan kualitas daging, karena lemak menentukan cita rasa dan aroma daging (Soeparno, 2005). Alternatif untuk membuat produk olahan daging ayam petelur afkir dengan cara dibuat abon, karena abon dapat meningkatkan kualitas cita rasa, daya simpan, nutrisi dan fisik dari daging mentah.

Metode pemasakan dan lokasi otot berpengaruh terhadap kualitas daging. Lokasi otot dada mempunyai kualitas lebih baik dibanding dada. Daging paha lebih alot dibanding daging dada (Soeparno, 2005). Salah satu metode pemasakan untuk mempertahankan kualitas daging dengan cara merebus daging selama 15 menit pada suhu $70-75^{\circ} \mathrm{C}$ (Sutaryo dan Mulyani 2004).

Penelitian bertujuan untuk mengetahui pengaruh lama perebusan dan lokasi otot terhadap kualitas kimia dan organoleptik abon ayam petelur afkir, serta interaksi antara lama perebusan dan lokasi otot.

\section{MATERI DAN METODE}

Bahan yang digunakan adalah daging ayam petelur afkir bagian dada dan paha yang berasal dari peternakan ayam petelur milik Bapak Samino beralamat Desa Ngemplak Pakis, Kecamatan Jumantono, Kabupaten.
Preparasi daging dimulai dengan pemotongan secara islami (Nuhriawangsa, 1999), prosesing karkas dan deboning, sehingga dihasilkan daging dada dan paha (Soeparno, 2005). Pembuatan abon ayam menggunakan metode Sutaryo dan Mulyani (2004). Bumbu yang digunakan sesuai dengan bumbu yang digunakan oleh Ariyanti (2003).

Peubah penelitian yang diamati adalah kadar air (AOAC, 1995), kadar lemak dengan ekstraksi Soxhlet (Atkinson et al., 1972), kadar protein dengan metode Biuret (AOAC, 1995) dan uji organoleptik (Kartika et al., 1988). Skor organoleptik dengan modifikasi menurut Lawrie (1995), yaitu: juisi $\quad(1$ = tidak juisi, 2 = kurang juisi, $3=$ juisi), flavor $(1=$ tidak gurih, $2=$ kurang gurih, 3 = gurih) dan hedonik ( $1=$ tidak suka, 2 = kurang suka, 3 = suka).

Rancangan percobaan yang digunakan dalam penelitian adalah Rancangan Acak Lengkap (RAL) Pola Faktorial 3 x 2 (Hanafiah, 2004). Faktor pertama lama perebusan $(15,30$ dan 45 menit) dan faktor kedua lokasi otot (dada dan paha). Sampel perlakuan terdiri dari 3 ulangan. Jika terdapat perbedaan tiap aras perlakuan dilanjutkan dengan uji jarak berganda Duncan's New Multiple Range Test (DMRT).

\section{HASIL DAN PEMBAHASAN}

\section{Kualitas Kimia}

Hasil perhitungan statistik kualitas kimia abon dari daging dada dan paha ayam petelur afkir dengan lama waktu perebusan 15, 30 dan 45 menit disajikan pada Tabel 1.

Hasil analisis statistik menunjukkan perbedaan yang sangat nyata $(\mathrm{P}<0,01)$ pada lama waktu perebusan terhadap kadar air dan protein terlarut (Tabel 1). Lama waktu perebusan mengalami peningkatan dengan diikuti penurunan kadar air. Kadar protein mengalami penurunan pada level waktu perebusan dibanding kontrol. Lama pemasakan dapat mempengaruhi kandungan nutrisi daging (Nuhriawangsa, 2004). 
Tabel 1. Rerata kadar air, protein dan lemak abon dari daging dada dan paha ayam petelur afkir dengan lama waktu perebusan 15, 30 dan 45 menit.

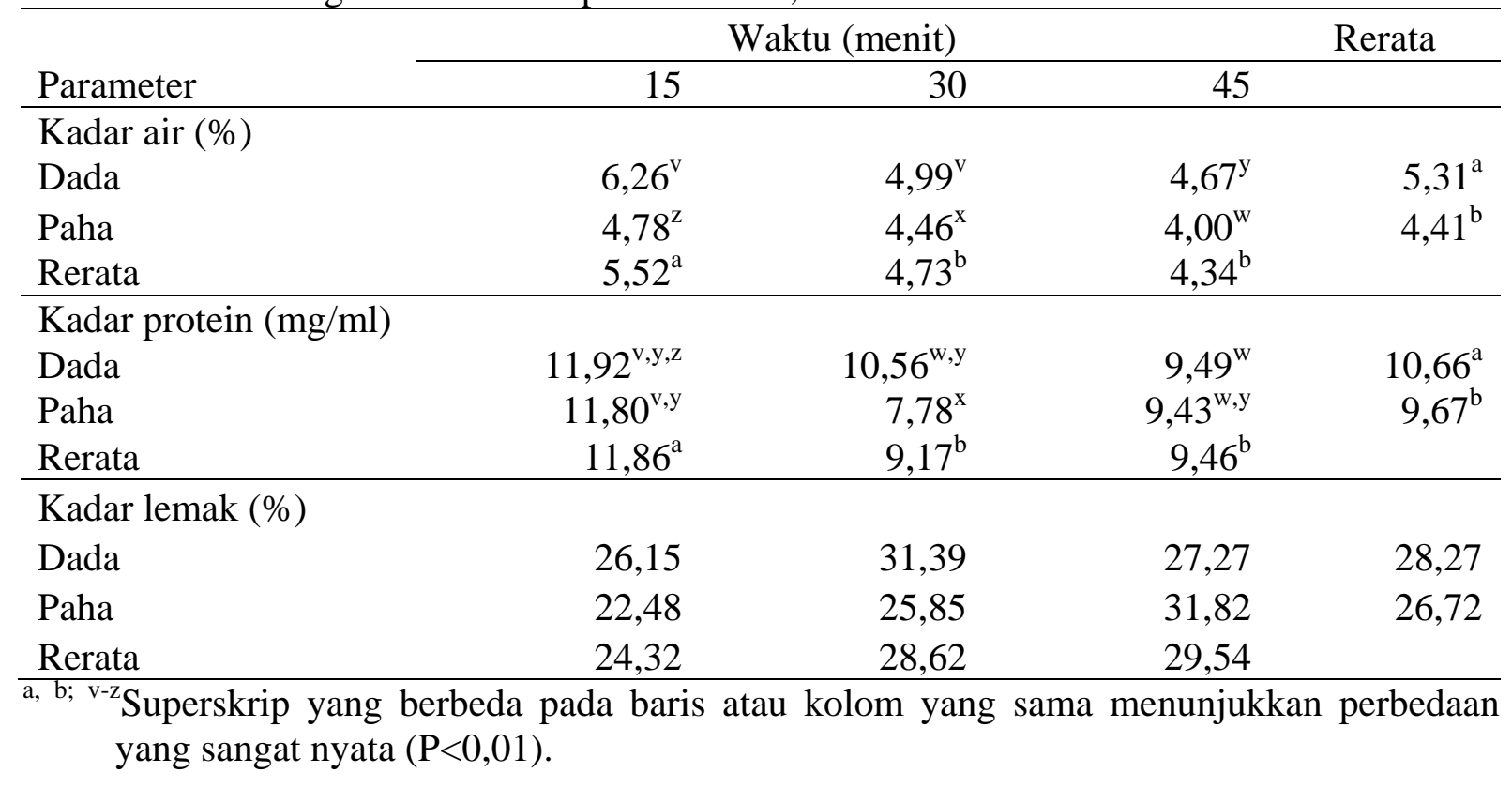

Daging yang dimasak dengan waktu pemasakan bertambah dapat mengakibatkan bertambahnya jumlah cairan daging yang keluar, sehingga dapat menurunkan kandungan air daging (Domiszewski et al., 2011; Dawson et al., 2012) dan kandungan protein terlarut daging (Nuhriawangsa dan Kartikasari, 2006). Menurut Kusnandar (2010) pada suhu $55-75^{\circ} \mathrm{C}$ protein mengalami denaturasi. Pemasakan dapat menurunkan kualitas protein jaringan ikat daging karena denaturasi, sehingga dapat meningkatkan jumlah cairan yang keluar dari daging dengan meningkatnya solubilitas protein daging (Wattanachant et al., 2005). Kehilangan kadar air terjadi selama proses pembuatan abon pada saat perebusan. Perebusan menyebabkan cairan daging tereksudasi dan struktur tersier protein daging mengalami denaturasi, sehingga kemampuan daya mengikat air daging hilang. Hal ini yang menyebabkan kadar air dan protein terlarut abon mengalami penurunan dibanding kontrol pada aras lama waktu pemasakan.

Hasil analisis statistik menunjukan perbedaan yang tidak nyata pada lama waktu perebusan terhadap kandungan lemak daging dan terdapat kecenderungan kenaikan kandungan lemak daging (Tabel 1). Nuhriawangsa (2004) menyatakan bahwa kandungan lemak meningkat dengan bertambahnya waktu pemasakan. Penurunan kandungan protein terlarut dan kandungan air diikuti dengan kenaikan kandungan lemak abon daging ayam petelur afkir. Nuhriawangsa dan Sudiono (2007) menyatakan bahwa kenaikan kandungan lemak akan diikuti oleh penurunan kandungan protein terlarut dan kandungan air pada daging itik afkir. Kenaikan kandungan lemak disebabkan karena keluarnya air akibat pemasakan (Larsen et al., 2010; Domiszewski et al., 2011). Pemanasan dapat menyebabkan denaturasi protein, sehingga cairan daging tereksudasi dari mikrostruktur daging. Selain itu terbentuk ikatan kimia hidrofilik berupa emulsi lemak dan menggantikan cairan daging yang keluar untuk mengisi mikrostruktur daging. Hal ini terjadi karena pemanasan menggunakan suhu $60-75^{\circ} \mathrm{C}$ (Soeparno, 2005). Peristiwa tersebut yang mengakibatkan terjadinya kenaikan kandungan lemak abon.

Hasil analisis menunjukan terdapat interaksi $(\mathrm{P}<0,01)$ antara aras lama waktu perebusan dan lokasi otot. Daging paha 
mengalami penurunan kandungan protein dan air lebih tinggi dibanding daging dada pada lama waktu perebusan yang sama. Daging dada tersusun oleh serabut otot putih dan daging paha tersusun oleh serabut otot merah (Brodal, 2010). Serabut otot merah menyusun otot yang mempunyai aktifitas gerak. Otot yang aktif mempunyai struktur lebih padat dibanding otot yang pasif (Soeparno, 2005), karena mempunyai jaringan ikat yang lebih tinggi (Gerrard, 1977). Kecepatan transfer panas mempengaruhi kondisi daging yang dimasak, daging dada termasuk daging yang mempunyai kecepatan transfer panas lambat (Siripon et al., 2007). Hal ini disebabkan karena tersusun oleh serabut otot putih yang mempunyai struktur yang kurang padat. Pemanasan mengakibatkan perubahan solubilitas protein, sehingga terjadi penurunan kekuatan protein miofibrilar dan pengeluaran air dari dalam mikrostruktur daging (Wang et al., 2009). Kecepatan perambatan panas daging paha lebih cepat dibanding daging dada, sehingga jumlah kandungan air dan protein yang keluar dari daging lebih tinggi dibanding daging dada. Hal tersebut menyebabkan daging paha mengalami penurunan kandungan protein dan air lebih tinggi dibanding daging dada pada lama waktu perebusan yang sama.

Hasil analisis statistik menunjukkan perbedaan yang sangat nyata $(\mathrm{P}<0,01)$ pada lokasi otot terhadap kadar air dan protein terlarut (Tabel 1). Daging dada mempunyai kandungan air dan protein lebih tinggi dibanding daging paha. Hal ini sesuai dengan penelitian Nuhriawangsa (1994) bahwa daging dada mempunyai kandungan air dan protein lebih tinggi dibanding daging paha. Soeparno (2005) bahwa daging dada ayam tersusun atas serabut otot putih dan mempunyai kandungan protein lebih tinggi dibanding dengan daging yang tersusun oleh serabut otot merah (paha). Protein daging dada tersusun oleh protein dan asam amino yang mempunyai sifat hidrofilik. Menurut Florence dan Attwood (2011) protein yang bersifat hidrofilik tersusun atas asam amino yang bersifat hidrofilik, sehingga mempunyai sifat mengikat air. Hal tersebut yang menyebabkan daging dada mempunyai kandungan protein dan air lebih tinggi dibanding daging paha.

Hasil analisis statistik menunjukan perbedaan yang tidak nyata pada lokasi otot terhadap kandungan lemak daging (Tabel 1). Hal ini tidak sesuai dengan pendapat Soeparno (2005) yang menyatakan bahwa daging paha mempunyai kandungan lemak lebih tinggi dibanding daging dada. Hal ini dimungkinkan karena masuknya minyak ke dalam daging ketika terjadi proses penggorengan saat pembuatan abon. Menurut Soriano-Santos (2010) proses penggorengan menyebabkan masuknya lemak ke dalam daging.

Hasil analisis menunjukan tidak terdapat interaksi antara aras lama waktu pemasakan dan lokasi otot terhadap kandungan lemak. Hal ini menunjukan tidak adanya hubungan antara aras lama waktu perebusan dan lokasi otot. Daging yang dimasak menggunakan pemanasan dapat mengakibatkan peningkatan keluarnya cairan daging (Wang et al., 2009). Cairan daging yang tereksudasi tersebut termasuk lemak (Soeparno, 2005). Salah satu proses dalam pembuatan abon dengan cara penggorengan (Sutaryo dan Mulyani, 2004). Pada proses penggorengan lemak dapat masuk ke dalam daging (Dawson et al., 2012) dengan mengisi kembali kompartemen daging. Hal tersebut yang menyebabkan tidak terdapat interaksi antara lama waktu perebusan dan lokasi otot.

Kualitas gizi manusia dinilai dengan konsumsi protein dengan melihat angka kecukupan protein per kapita per orang. Kualitas protein dinilai dengan melihat perbandingan rerata konsumsi protein hewani dan nabati. Protein hewani lebih berkualitas dibanding protein nabati dan protein dari daging ayam merupakan penyumbang terbesar dari peternakan. Daging merupakan sumber protein hewani dengan kualitas yang tinggi karena tingginya kandungan asam amino. Kualitas gizi yang tinggi ditentukan dengan tingginya kualitas protein yang dikonsumsi(Setiawan, 2006). 
Tabel 2. Rerata juisi, flavor dan kesukaan abon ayam dengan lama waktu perebusan 15, 30 dan 45 menit pada daging dada dan paha

\begin{tabular}{lcccc}
\hline & & Waktu & & Rerata \\
\cline { 2 - 5 } Parameter & 15 & 30 & 45 & \\
\hline Juisi & & & & \\
Dada & 1,65 & 1,95 & 2.10 & $1,90^{\mathrm{B}}$ \\
Paha & 2,00 & 2,30 & 2,35 & $2,22^{\mathrm{A}}$ \\
Rerata & 1,83 & 2,13 & 2,23 & \\
\hline Flavor & & & & \\
Dada & 2,00 & 2,50 & 2,65 & 2,38 \\
Paha & 2,15 & 2,05 & 2,30 & 2,17 \\
Rerata & 2,08 & 2,28 & 2,48 & \\
\hline Kesukaan & & & & \\
Dada & 2,00 & 2,50 & 2,65 & 2,38 \\
Paha & 2,15 & 2,05 & 2,30 & 2,17 \\
Rerata & 2,08 & 2,28 & 2,48 & \\
\hline
\end{tabular}

Keterangan : Nilai derajat skala juisi abon : 0,00-2,00 (tidak juisi), 2,1-3,0 (kurang juisi), 3,1-4,0 (juisi).

Nilai derajat skala flavor abon : 0,00-2,0 (tidak gurih), 2,1-3,0 (kurang gurih), 3,1-4,0 (gurih).

Nilai derajat skala kesukaan abon : 0,00-2,0 (tidak suka), 2,1-3,0 (kurang suka), 3,1-4,0 (suka).

\section{Kualitas Organoleptik}

Hasil perhitungan statistik kualitas organoleptik abon ayam petelur afkir dengan lama waktu perebusan 15, 30 dan 45 menit pada bagian daging dada dan paha disajikan pada Tabel 2.

Hasil analisis statistik menunjukan perbedaan yang tidak nyata pada lama waktu perebusan terhadap juisi, flavor dan kesukaan (Tabel 2). Menurut Nuhriawangsa (2002) dan Irma et al. (1997) perebusan dapat mengakibatkan hidrolisis protein dan eksudasi cairan (air bebas, air immobilisasi dan gap cairan daging) daging, sehingga daging menjadi keras dan kering. Hal ini menyebabkan hasil kualitas organoleptik tidak berbeda nyata, karena panelis sukar untuk mendeteksi juisi, flavor dan kesukaan, mengingat pengujian menggunakan panelis yang tidak terlatih. Menurut Kartika et al. (1988) panelis tidak terlatih mempunyai karakteristik hanya mengemukakan pendapatnya secara spontan dan tidak membandingkan sampel standar atau sampel yang diuji.
Hasil analisis statistik menunjukan perbedaan yang tidak nyata pada lokasi otot terhadap flavor dan kesukaan (Tabel 2). Salah satu parameter untuk menilai flavor adalah dengan melihat bau atau aroma (Lawrie, 1995). Poly Unsaturated Fatty Acid (PUFA) merupakan asam lemak yang dapat mempengaruhi bau (Rimer dan Givens, 2009). Poly Unsaturated Fatty Acid dalam daging mengalami perubahan karena pemasakan (Kouba et al., 2008), sehingga menyebabkan terjadinya pengurangan flavor pada daging. Hal ini yang menyebabkan panelis mengalami kesulitan dalam membedakan flavor antara daging dada dan paha, sehingga menyebabkan tidak terjadinya perbedaan flavor. Menurut Soeparno (2005) flavor merupakan salah satu faktor yang mempengaruhi tingkat kesukaan. Hasil menunjukan flavor tidak berpengaruh terhadap kesan kesukaan lokasi otot, sehingga kesan kesukaan panelis juga tidak berbeda.

Hasil analisis statistik menunjukan perbedaan yang nyata $(\mathrm{P}<0,01)$ pada lokasi otot terhadap juisi (Tabel 2). Daging paha 
lebih juisi dibanding daging dada. Hal ini sesuai dengan pendapat Williams dan Damron (1998). Daging paha mempunyai aktivitas gerak yang lebih aktif, sehingga dimungkinkan untuk terjadinya penimbunan lemak marbling. Lemak marbling merupakan lemak yang dapat mempengaruhi tingkat juisi dari daging (Soeparno, 2005). Lemak marbling dengan jumlah sedikit mengakibatkan nilai juisi rendah (Gregory, 2010). Daging paha mempunyai kandungan lemak marbling lebih tinggi dibanding daging dada, sehingga daging paha lebih juisi dibanding daging dada.

Hasil analisis menunjukan tidak terdapat interaksi antara aras lama waktu pemasakan dan lokasi otot terhadap juisi, flavor dan kesukaan. Hal ini menunjukan tidak adanya hubungan antara aras lama waktu perebusan dan lokasi otot terhadap kesan organoleptik. Hasil penelitian tersebut disebabkan karena kesan flavor dan kesukaan tidak dapat dideteksi oleh panelis. Menurut Kartika et al. (1988) kesan organoleptik panelis dipengaruhi oleh berbagai macam faktor dan faktor tersebut harus dapat menimbulkan penerimaan secara utuh oleh panelis.

\section{KESIMPULAN}

Abon daging ayam petelur afkir dengan waktu perebusan 30 menit pada daging dada dan 45 menit pada daging paha mempunyai kualitas terbaik.

\section{DAFTAR PUSTAKA}

Ariyanti, N. D., 2003. Sifat Fisik, Kimia, Mikrobiologi dan Organoleptik Abon Ayam Kampung dengan Penambahan Kunyit selama Penyimpanan. Skripsi Sarjana Peternakan. Fakultas Peternakan Institut Pertanian Bogor, Bogor.

AOAC, 1995. Official Methods of Analysis. $16^{\text {th }}$ ed. AOAC Int. Washington D. C.

Atkinson., T., V. R. Fowler, G. A. Garton, and A. Lough, 1972. A rapid methode for the determination on lipid in animal tissues. Analyst, London. 97:563-568.
Brodal, P., 2010. The Central Nervous System: Structure and Functions. Oxford University Press Inc., New York.

Dawson, L. P., S. Mangalassary, and B. W. Sheldon, 2012. Thermal Processing of Poultry Product. In: Thermal Food Processing: New Technologies and Quality Issues. D. W. Sun, Ed. CRC Press, USA.

Domiszewski, Z., G. Bienkiewicz, and D. Plust, 2011. Effects of different heat treatments on lipid quality of striped catfish (Pangasius hypophthalmus). Acta Sci. Pol. Technol. Aliment. 10(3):359-373.

Florence, A. T., and D. Attwood, 2011. Peptides, Proteins and Other Biopharmaceuticals. In: Physicochemical Principles of Pharmacy. Pharmaceutical Press Pub., London, United Kingdom. Page:451-476.

Gerrard, F., 1977. Meat Technology. Nortwood Pub., Ltd., London.

Gillespie, J. R., and F. B. Flanders, 2010. Modern Livestock and Poultry Production: Feeding, Manajement, Housing, and Equipment. $8^{\text {th }}$ ed. Delmar, Ltd. New York, USA. Page:674-695.

Gregory, N. G., 2010. How climatic changes could affect meat quality. Food Research Int. 43(7): 1866-1873.

Hanafiah, K. 2004. Rancangan Percobaan Teori dan Aplikasi. Raja Grafindo Persada, Jakarta.

Irma, K., Z. A. Dede dan T. S. Ela, 1997. Pengaruh Konentrsi Getah Pepaya (Carica papaya, Linn) dan Waktu Hidrolisis terhadap Hidrolisat Protein Kepala Udang Windu (Karapaks penaeus modon). Dalam: Proseding Seminar Nasional Tekhnologi Pangan. Denpasar, Bali. Halaman: 271-282.

Kartika, B., P. Hastuti dan W. Supartono, 1988. Pedoman Uji Inderawi Bahan Pangan. PAU Pangan dan Gizi, Universitas Gadjah Mada, Yogyakarta.

Kouba, M., F. Benatmane, J. E. Blochet, and J. Mourot, 2008. Effect of a linseed diet on lipid oxidation, fatty acid composition of muscle, perirenal fat, and raw and cooked rabbit meat. Meat Sci. 80(3):829-834.

Kusnandar, F., 2010. Mengenal Sifat Lemak dan Minyak. Departemen Ilmu Teknologi Pangan - 
IPB. http://itp.fateta.ipb.ac.id/id. Diakses: 12 Desember 2010.

Larsen, D., S. Y. Quek, and L. Eyres, 2010. Effect of cooking method on the fatty acid profile of New Zealand King Salmon (Oncorhynchus tshawytscha). Food Chemist. 119(2):785-790.

Lawrie, R. A., 1995. Meat Science. Penerjemah : A. Parakkasi. UI-Press, Jakarta.

Nuhriawangsa, A. M. P., 1994. Komposisi Kimia Daging Dada dan Non Dada pada Karkas Ayam Broiler Jantan dan Betina Umur Enam Minggu. Skripsi Sarjana Peternakan. Fakultas Peternakan, UGM, Yogyakarta.

Nuhriawangsa, A. M. P., 1999. Pengantar Ilmu Ternak dalam Pandangan Agama Islam: Suatu Tinjauan Tentang Fiqih Ternak. Buku Diktat. Program Studi Produksi Ternak, Fakultas Pertanian, UNS, Surakarta.

Nuhriawangsa, A. M. P dan Sudiyono, 2002. Kegunaan Pemasakan untuk Meningkatkan Kualitas Daging Itik Afkir. Laporan Penelitian Dosen Muda. Fakultas Pertanian, UNS, Surakarta.

Nuhriawangsa, A. M. P., 2004. Pengaruh Waktu dan Lama Pemanggangan terhadap Kualitas Daging Itik Afkir. Jurnal Pengembangan Peternakan Tropis UNDIP. Edisi Khusus Nopember. Halaman: 122-127.

Nuhriawangsa, A. M. P. and L. R. Kartikasari, 2006. Utility of Trimming Method and Roasting Duration for Increasing Meat Quality of Post-Laying Duck. In: Proceeding Animal Production and Sustainable Agriculture in the Tropic. The $4^{\text {th }}$ International Seminar on Tropical Animal Production (ISTAP). Faculty of Animal Science, GMU, Yogyakarta. Page: 110-115.

Nuhriawangsa, A. M. P dan Sudiono, 2007. Kegunaan Waktu dan Cara Pemasakan untuk Meningkatkan Kualitas Daging Itik Afkir. Laporan Penelitian Dosen Muda. Fakultas Pertanian, UNS, Surakarta.
Rasyaf, M., 2010. Pengelolaan Produksi Telur. Edisi ke-8. Penerbit Kanisius, Yogyakarta.

Rymer, G., and D. I. Givens, 2009. The effect of feeding stearidonic acid enriched soy oil to broilers on the fatty acid composition and sensory characteristics of chicken meal. Brit. Poult. 5(1):44-45. (Abstract).

Setiawan, N., 2006. Perkembangan Konsumsi Protein Hewani di Indonesia (Analisis Hasil Susenas 1999-2004). Fakultas Peternakan, Universitas Padjajaran, Bandung.

Soriano-Santos, J., 2010. Dietary Products for Special Populations. In: Hand Book of Poultry Science and Tchnolgy. $2^{\text {nd }}$ ed. I. Guerrero-Legarreta and Y. H. Hui, Eds. John Wiley and Sons, Inc. Canada. Page: 275-292.

Siripon, K., A. Tansakul, G. S. Mittal, 2007. Heat transfer modeling of chicken cooking in hot water. Food Research Int. 40(7): 923-930.

Sutaryo dan S. Mulyani, 2004. Pengetahuan Bahan Olahan Hasil Ternak dan Standar Nasional Indonesia (SNI). Komplek Taru Budaya Ungaran, Semarang.

Soeparno, 2005. Ilmu dan Teknologi Daging. Cet. Ke-4. Gajah Mada University Press, Yogyakarta.

Wang, R. R., X. J. Pan, and Z. Q. Peng, 2009. Effects of heat exposure on muscle oxidation and protein functionalities of pectoralis majors in broilers. Poult. Sci. 88 :1078-1084.

Wattanachant, S., S. Benjakul, and D. A. Ledward, 2005. Effect of heat treatment on changes in texture, structure and properties of Thai indigenous chicken muscle. Food Chemistry. 93(2):337-348.

Williams, S. K., and B. I. Damron, 1998. Sensory and objective characteristics of broiler meat from commercial broilers fed rendered whole-hen meal. Poult. Sci. 77:329-333. 